\title{
METODE PEMBELAJARAN MATA PELAJARAN ALQURAN HADIS PADA MAN 2 BUKITTINGGI
}

\author{
Yopi M \\ IAIN Bukittinggi,yopi06@yahoo.co.id \\ A. Rahman Ritonga \\ IAINBukittinggi, rabman_ritonga@iainbukittinggi.ac.id \\ Deswalantri \\ IAINBukittinggi, deswalantri@iainbukittinggi.ac.id
}

Diterima: 4 Januari 2019

Direvisi : 13 April 2019

Diterbitkan: 30 Juni 2019

\begin{abstract}
The background of this study is based on the author's interest in examining further the methods used by teachers on the Qur'anic Hadith subjects in class XI GPA at MAN 2 Bukittinggi. Students do not feel bored and excited in learning because teachers use methods that are not monotonous. The type of research I use is field research with a qualitative approach. The key informants in this study were teachers of the Qur'anic Hadith subject, and supporting informants in this study were students of class XI majoring in GPA. Data collection techniques that the authors use are observation, interviews, and documentation. Then the data obtained from the informants were analyzed using qualitative descriptive methods. The results of this study indicate that the learning method of the Koran used by the teachers of the Koran subjects in class XI GPA can be concluded that the teacher mostly uses the lecture method, but interspersed with other purposes, such as discussion methods, questions and answers, and different ways.
\end{abstract}

Keywords: Learning, Method, Alquran Hadis.

\begin{abstract}
Abstrak
Latar belakang penelitian ini didasari dari kunikan yang penulis temui dan untuk meneliti lebih lanjut metode yang digunakan oleh guru pada mata pelajaran Alquran Hadis pada kelas XI IPK di MAN 2 Bukittinggi. Siswa tidak merasa bosan dan bersemangat dalam belajar, karena guru menggunakan metode yang tidak monoton. Jenis penelitian yang penulis gunakan adalah penelitian lapangan (field research) dengan pendekatan kualitatif. Adapun informan kunci pada penelitian ini adalah guru mata pelajaran AlquranHadis, dan informan pendukung dalam penelitian ini adalah siswa kelas XI jurusan IPK. Teknik pengumpulan data yang penulis gunakan adalah observasi, wawancara, dan dokumentasi. Kemudian data yang didapat dari informan dianalisa dengan teknik deskriptif kualitatif. Hasil penelitian ini menunjukkan bahwa metode pembelajaran Alquran Hadis yang diterapkan oleh guru mata pelajaran AlquranHadis pada kelas XI IPK dapat disimpulkan bahwa guru kebanyakan menggunakan metode ceramah, namun diselingi dengan metode lain, seperti metode diskusi, tanya jawab dan metode metode lainnya.
\end{abstract}

Kata Kunci: Pembelajaran, Metode, Alquran Hadis.

\section{PENDAHULUAN}

Pendidikan merupakan suatu proses pendewasaan peserta didik melalui pembelajaran secara sadar dan terencana untuk secara aktif mengoptimalkan potensi yang ada pada diri peserta didik, sehingga terbentuk watak, karakter, dan kepribadian sebagai manusia seutuhnya. Pendidikan merupakan kunci utama terbentuknya sumber daya manusia yang kompeten untuk membangun 
bangsa. Istilah pendidikan yang pada dasarnya adalah upaya seseorang untuk sadar dalam mengembangkan potensi yang ada dalam diri individu, sehingga pendidikan mempunyai peran yang sangat penting untuk perkembangan dan kelangsungan kehidupan suatu bangsa.

Menurut tokoh nasional Indonesia Ki Hajar Dewantara yang dikutip oleh Muri Yusuf dalam bukunya Pengantar Ilmu Pendidikan merumuskan bahwa pengertian pendidikan adalah sebagai berikut:

Pendidikan diartikan sebagai daya upaya untuk memberikan tuntunan pada segala kekuatan kodrat yang ada pada anak-anak, agar mereka baik sebagai manusia maupun sebagai anggota masyarakat dapat mencapai keselamatan dan kebahagiaan hidup lahir dan batin yang setinggi-tingginya. ${ }^{1}$ Selaras dengan pengertian di atas, UU

No. 20 Tahun 2003 Bab I Pasal 1 tentang Sistem Pendidikan Nasional juga menjelaskan bahwa:

Pendidikan adalah suatu usaha sadar dan terencana untuk mewujudkan suasana belajar dan proses pembelajaran agar peserta didik secara aktif mengembangkan potensi dirinya untuk memiliki kekuatan spiritual keagamaan, pengendalian diri, kepribadian, kecerdasan, akhlak mulia, serta keterampilan yang diperlukan dirinya, masyarakat, bangsa dan negara. $^{2}$

Dari uraian di atas dapat ditarik kesimpulan bahwa tujuan dari pendidikan adalah membentuk manusia seutuhnya, yakni manusia pancasila sejati serta berlangsung seumur hidup, di dalam maupun di luar sekolah dan diharapkan agar menjadi manusia atau warga masyarakat yang terampil bekerja, mampu menyesuaikan diri dengan sekitarnya

1 Muri Yusuf, Pengantar Ilmu Pendidikan, (Jakarta: Ghalia Indonesia, 1986), 21

2 Ed.,Undang-Undang Republuk. Indonesia No 20 Tabun 2003 tentang Sistem Pendidikan Nasional, (Jakarta: Sinar Grafika, 2009), 3 dan mengatasi masalah dalam kehidupannya pada masa sekarang dan masa yang akan datang. ${ }^{3}$

Allah SWT berfirman dalam Alquran surat Al-Mujadalah ayat 11 sebagai berikut :

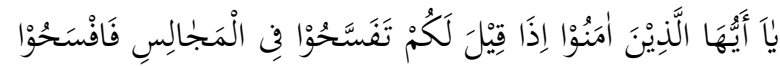

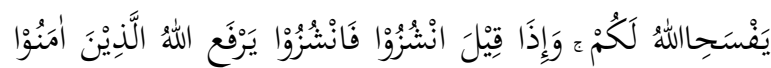

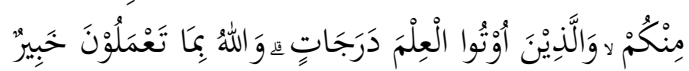
Artinya : Wabai orang-orang yang beriman! apabila dikatakan kepadamu, "Berlapang-lapanglah dalam majlis", maka lapangkanlah niscaya Allah akan memberi kelapangan untukmu. Dan apabila dikatakan: "Berdirilah kamu", maka berdirilah, niscaya Allah akan mengangkat derajat orang-orang yang beriman di antaramu dan orang-orang yang diberi ilmu beberapa derajat. Dan Allab Maha Mengetahui apa yang kamu kerjakan. (Al Mujadalah $: 11)^{4}$

Dari ayat di atas dapat dilihat betapa Allah SWT memuliakan dan meninggikan orang-orang yang belajar dan berilmu pengetahuan beberapa derajat. Terlebih lagi orang-orang yang mau memperdalam ilmu agama dan mengamalkannya dalam kehidupan sehari-hari. Seperti orang-orang yang belajar di madrasah-madrasah atau lembaga-lembaga pendidikan Islam. $^{5}$

Madarasah Aliyah adalah salah satu lembaga pendidikan Islam yang berada di bawah naungan kementerian agama. Mata pelajaran Alquran Hadis adalah bagian dari mata pelajaran pendidikan agama Islam pada Madrasah Aliyah yang dimaksudkan untuk memberikan motivasi, bimbingan, pemahaman, kemampuan dan penghayatan terhadap isi yang terkandung dalam Alquran dan Hadis. Sehingga dapat diwujudkan dalam

\footnotetext{
3 Oemar Hamalik, Media Pembelajaran, (Bandung: Citra Aditya Bakti, 1989), 2

4 Al-Qur'an dan Terjemahannya, (Jakarta: Pustaka Alfatih, 2011), 543.

5 Indah Muliati and Muhamad Rezi, "Tujuan Pendidikan Dalam Lingkup Kajian Tafsir Tematik Pendidikan," Islam Transformatif: Journal of Islamic Studies 1, no. 2 (2018): https://doi.org/10.30983/IT.V1I2.475., 92.
} 
perilaku sehari-hari sebagai manifestasi iman dan takwa kepada Allah SWT. Mata pelajaran Alquran Hadis dijadikan sebagai salah satu pelajaran pokok yang diajarkan pada seluruh siswa kelas X, XI, dan XII. Tujuan pembelajaran Alquran Hadis adalah meningkatkan kecintaaan siswa terhadap Alquran dan Hadis. Membekali siswa dengan dalil-dalil yang terdapat dalam Alquran dan Hadis sebagai pedoman dalam menyikapi dan menghadapi kehidupan.

Agar tujuan pembelajaran Alquran Hadis tersebut tercapai, guru perlu merancang dan mendesain proses pembelajaran yang sesuai. Guru perlu menggunakan pendekatan, strategi dan metode pembelajaran yang menarik agar dapat memudahkan siswa dalam memahami materi yang diajarkan serta dapat meningkatkan motivasi siswa untuk meningkatkan kegiatan belajar mengajar. Sehingga siswa tidak merasa jenuh dan bosan pada saat guru menyampaikan materi pembelajaran. Materi yang diajarkan kepada siswa adalah materi yang sudah ada pada kurikulum yang ditetapkan oleh pemerintah. Materi tersebut diberikan dalam bentuk ayatayat Alquran dan Hadis yang materinya dituntut adanya hafalan siswa dari materi tersebut. Karena materi hafalan itu berbentuk ayat-ayat Alquran dan Hadis yang ditulis dalam bahasa Arab, makanya menimbulkan kesulitan tersendiri bagi siswa untuk menguasainya. Sehingga membutuhkan strategi dan metode serta taktik dan teknik yang menarik dalam proses pembelajaran.

Metode adalah cara yang digunakan untuk mengimplementasikan rencana yang sudah disusun dalam kegiatan nyata agar tujuan yang telah disusun tercapai secara optimal. $^{6} \quad$ Metode mengajar memegang peranan penting dalam mencapai tujuan atau keberhasilan pembelajaran. Seorang guru akan

6 Wina Sanjaya, Strategi Pembelajaran, Jakarta: Kencana, 2006), 147 berhasil dalam tugas mengajar, bila dengan metode atau teknik yang digunakannya ia mampu memotivasi serta memancing daya dan gairah belajar murid-muridnya. Beberapa hal yang perlu diperhatikan yang berhubungan dengan metode yaitu:

1. Metode hanyalah salah satu jalan atau cara yang digunakan oleh guru dalam mengajar dan bukan tujuan.

2. Tidak ada satu metode yang paling baik.

3. Metode yang sesuai pun belum menjamin hasil yang baik secara otomatis.

4. Suatu metode yang baik bagi seorang guru belum tentu baik bagi guru lain.

Penerapan metode pembelajaran sangat penting dalam menunjang keberhasilan kegiatan belajar mengajar. Dengan metode pembelajaran yang tepat akan mampu meningkatkan prestasi belajar siswa. Kegiatan belajar mengajar yang biasa-biasa saja dengan tampa perubahan dari waktu ke waktu akan membuat siswa cepat bosan. Disinilah kreativitas guru sangat diperlukan dan menentukan dalam kesuksesan pembelajaran. Dengan penerapan sebuah metode pembelajaran yang tepat akan menjadikan siswa bersemangat dalam mengikuti pembelajaran. siswa akan merasa penasaran terhadap kreativitas guru mengenai apa yang akan diajarkan besoknya lagi. Ingatan siswa akan sangat tajam karena pembelajaran dialami mereka dengan memaksimalkan seluruh indera yang ada.

Metode pembelajaran jumlahnya sangat banyak, tetapi tidak semua metode dapat diterapkan dalam berbagai pembelajaran. Untuk itu seorang guru harus memilah-milah metode pembelajaran yang tepat dan baik untuk diterapkan. Metode yang dilakukan betul-betul menarik, menyenangkan, dan menantang bagi peserta didik. Setiap metode memiliki kekurangan dan kelebihan masingmasing, namun, yang penting bagi guru 
metode manapun yang digunakan harus jelas tujuan yang akan dicapai. ${ }^{7}$

Apabila metode yang digunakan kurang tepat, maka seorang guru harus memperbaikinya dengan melakukan penelitian, mengikuti pelatihan, membaca berbagai buku metode pembelajaran, mengakses di internet dan sumber-sumber lainnya. Penguasaan metode pembelajaran merupakan bagian penting untuk mengembangkan profesinya sebagai seorang guru yang profesional. ${ }^{8}$

Dalam ajaran Islam dapat dilihat betapa pentingnya penggunaan metode pembelajaran, seperti tercantum dalam Alquran surah An Nahl ayat 125, yang berbunyi:

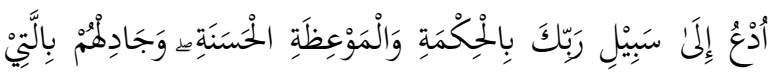

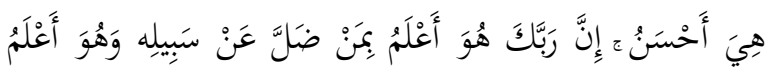

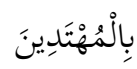

Serulah (manusia) kepada jalan Tuhan-mu dengan bikmah dan pengajaran yang baik dan bantablab mereka dengan cara yang baik. Sesunggubnya Tubanmu Dialah yang lebih mengetahui tentang siapa yang tersesat dari jalan-Nya dan Dialab yang lebib mengetahui orang-orang yang mendapat petunjuk. (An nabl: 125$)^{9}$

Ayat di atas menjelaskan tentang cara nabi berdakwah yang dapat dikaitkan dengan metode pembelajaran PAI. Dalam metode tersebut seorang guru menguasai metode untuk membentuk siswa yang berakhlak mulia. Dalam proses mengajar metode-metode yang harus dikuasai guru, misalnya metode ceramah, metode tanya jawab, metode diskusi, metode drill (penugasan), dan lain-lainnya. ${ }^{10}$

MAN 2 Bukittinggi adalah salah satu sekolah yang berbasis keagamaan yang berada di bawah naungan Kementerian Agama, yang

7 M. fadillah, Implementasi Kurikulum 2013 dalam pembelajaran SD/MI, SMP/MTs \& $S M A / M A$, (Yogyakarta : Ar-Ruzz Media, 2014), 189

8 Syahraini Tambak, Pendidikan Agama Islam Konsep Metode Pembelajaran PAI, (Yogyakarta: Graha Ilmu, 2004), 44-45

9 Al-Qur'an dan Terjemahannya..., 281

${ }^{10}$ Syahraini Tambak, Pendidikan Agama ..., 45 berlokasikan di jalan Panorama Baru, kelurahan Puhun Tembok, kecamatan Mandiangin Koto Salayan, kota Bukittinggi.

Sama dengan madrasah lainnya, di MAN 2 Bukittinggi ini juga terdapat mata pelajaran Alquran Hadis sebagai salah satu bagian dari mata pelajaran PAI. Pada mata pelajaran Alquran Hadis ini seorang guru tentunya memiliki metode tersendiri dalam proses belajar mengajar, agar apa yang menjadi tujuan dari pembelajaran ini dapat tercapai, tak ubahnya juga dengan guru Alquran Hadis di MAN 2 Bukittinggi ini.

Berdasarakan pengamatan dan wawancara awal yang penulis lakukan terhadap beberapa orang siswa, mereka pada umumnya bersemangat dalam belajar Alquran Hadis, dikarenakan guru yang mengajar mereka menggunakan metode yang bervariasi dalam mengajar. Seperti ungkapan dari salah seorang siswa yang bernama Rahmad Prayogi, dia menyebutkan bahwa:

"Kami sangat senang belajar Alquran Hadis dengan bapak Liswar, Karena beliau menarik dalam mengajar, tidak membuat kami mengantuk, dan apa yang beliau sampaikan selalu diselingi dengan guyonan, sehingga semangat kami yang mulai hilang jadi bangkit lagi." $" 11$

Senada dengan pendapat siswa di atas, penulis juga melakukan wawancara dengan guru mata pelajaran Alquran Hadis pada tanggal 23 November 2018, beliau menyatakan bahwa:

"Kebanyakan siswa tertarik dan merasa senang dalam proses belajar mengajar berlangsung, dengan artian tidak membedakan-bedakan materi dalam pembelajaran yang disampaikan. Walaupun ada satu-satu dari siswa yang terkadang tidak efektif dalam belajar.","12

11 Rahmad Prayogi (Siswa Kelas XI IPK 2), Wawancara, Bukittinggi, 23 November 2018

12 Guru Al-Qur'an Hadits MAN 2 Bukittinggi, Wawancara, tanggal 23 November 2018 
Guru Alquran Hadis disini adalah salah satu guru senior yang telah mengajar lama di MAN 2 Bukittinggi. Penulis cukup salut dengan beliau karena beliau menarik dalam mengajar, hal inilah yang membuat penulis termotivasi untuk meneliti dan mengetahui lebih lanjut tentang metode pembelajaran Alquran Hadis yang beliau gunakan.

Dari uraian di atas, penelitian ini fokus kepada mengungkap dan mengeksplorasi metode pemebelajaran yang digunakan para Guru di MAN 2 Bukittinggi sehingga bisa membuat pembelajaran Quran-Hadis bisa menjadi menarik dan tidak membosankan.

\section{METODE PENELITIAN}

Berdasarkan jenis penelitiannya, penelitian ini merupakan penelitian lapangan ( field research). Ide pentingnya adalah bahwa peneliti berangkat ke lapangan untuk mengadakan pengamatan tentang sesuatu fenomena dalam suatu keadaan alamiah atau "in situ"13

Oleh karena itu, dalam penelitian ini peneliti menggunakan pendekatan kualitatif. Penelitian kualitatif adalah penelitian yang bermaksud untuk memahami fenomena tentang apa yang dialami oleh subjek penelitian. Misalnya perilaku, persepsi, motivasi, tindakan, dan lain-lain secara holistik, dan dengan cara deskripsi dalam bentuk katakata dan bahasa, pada suatu konteks khusus yang alamiah dan memanfaatkan berbagai metode alamiah. ${ }^{14}$

\section{LANDASAN TEORI}

Metode berasal dari bahasa yunani, yaitu metha dan hodos. Metha berarti melalui atau melewati dan hodos berarti jalan atau cara. Metode berarti jalan atau cara yag harus dilalui

13 Lexy J Moleong, Metodologi Penelitian Kualitatif, (Bandung: Remaja Rosda Karya, 2006), 26.

${ }^{14}$ Ibid. untuk mencapai tujuan tertentu. Dalam bahasa arab, metode disebut "thariqah". ${ }^{15}$

Dalam kegiatan belajar mengajar, metode sangat diperlukan oleh guru, dengan penggunaan yang bervariasi sesuai dengan tujuan yang ingin dicapai. ${ }^{16}$ Pengertian lain metode ialah teknik penyajian yang dikuasai guru untuk mengajar atau menyajikan bahan pelajaran kepada siswa di dalam kelas, baik secara individual atau secara kelompok/ klasikan. Agar pelajaran itu dapat diserap, dipahami dan dimanfaatkan oleh siswa dengan baik. ${ }^{17}$ Menurut Ahmad Tafsir, metode adalah cara yang paling tepat dan cepat dalam melakukan sesuatu. ${ }^{18}$

\section{Sedangkan pembelajaran atau}

pengajaran menurut Degeng adalah upaya untuk membelajarkan siswa. Dalam pengertian ini secara implisit dalam pengajaran terdapat kegiatan memilih, menetapkan, dan mengembangkan metode untuk mencapai hasil pembelajaran yang diinginkan. Pemilihan, penetapan, dan pengembangan metode ini didasarkan pada kondisi pengajaran yang ada. ${ }^{19}$

Metode pembelajaran merupakan caracara yang ditempuh guru untuk menciptakan situasi pengajaran yang menyenangkan dan mendukung bagi kelancaran proses belajar dan tercapainya prestasi belajar anak yang memuaskan. ${ }^{20} \quad$ Sedangkan metode pembelajaran dapat diartikan sebagai berikut:

1. Seluruh perencanaan dan prosedur maupun langkah-langkah kegiatan pembelajaran

15 Bukhari Umar, Ilmu pendidikan Islam (Jakarta: Amzah, 2010), 180

16 Pupuh Fathurrohman \& M. Sobry Sutikno, Strategi Belajar Mengajar (Bandung: PT. Refika Aditama, 2007), 15

17 Abu Ahmadi \& Joko Tri Prasetya, Strategi Belajar Mengajar, (Bandung: CV Pustaka Setia, 2005), 52.

18 Ahmad Tafsir, Metodologi Pengajaran Agama Islam (Bandung: PT. Remaja Rosdakarya, 2007), 9

19 Hamzah, Perencanaan Pembelajaran, (Jakarta: Bumi Aksara, 2008), 2.

${ }^{20}$ Wina Sanjaya, Strategi Pembelajaran Berorientasi Standar Proses Pendidikan, (Jakarta: Kencana, 2008), 127. 
termasuk pilihan cara penilaian yang akan dilaksanakan.

2. Sesuatu prosesdur, proses, jalan dan carayang teratur untuk melakukan pembelajaran. ${ }^{21}$

3. Cara yang digunakan guru dalam menjalankan fungsinya untuk mencapai tujuan pembelajaran. ${ }^{22}$

4. Cara-cara penyajian materi pelajaran yang dilakukan oleh pendidik agar terjadi proses pembelajaran pada diri peserta didik dalam upaya untuk mencapai tujuan. ${ }^{23}$

5. Cara yang digunakan untuk mengimplementasikan rencana yang sudah disusun dalam bentuk kegiatan nyata dan praktis untuk mencapai tujuan pembelajaran.

Sebagai seorang guru, tentunya mengetahui metode-metode pembelajaran di sekolah sangatlah penting. Tanpa mengetahui metode-metode pembelajaran, maka proses belajar mengajar tidak dapat dilaksanakan dengan baik. Oleh karena itu, untuk mendorong keberhasilan guru dalam proses belajar mengajar, guru seharusnya mengerti akan fungsi dan langkah-langkah pelaksanaan metode pembelajaran.

Dari penjelaskan di atas dapat di tarik kesimpulan bahwa metode pembelajaran merupakan cara-cara yang akan dipilih dan digunakan oleh seorang pendidik untuk menyampaikan materi pelajaran dalam proses pembelajaran sehingga akan memudahkan peserta didik menerima dan memahami materi yang dijelaskan oleh guru tersebut, sehingga tercapainya tujuan pembelajaran yang diinginkan.

\footnotetext{
${ }^{21}$ Suryono dan Hariyanto, Belajar dan Pembelajaran Toeri dan Konsep, (Bandung: Remaja Rosdakarya, 2017), 19.

${ }^{22}$ Hamzah B. Uno, Model Pembelajara Menciptakan Proses Belajar Mengajar yang Kreatif dan Efektif, (Jakarta: Bumi Aksara, 2008), 2

${ }^{23}$ Alizamar, Toeri Belajar dan Pembelajaran; Implementasi dalam Bimbingan Kelompok Belajar di Perguruan Tinggi, (Yogyakarta: Media Akademik, 2016), 31.
}

Mata pelajaran Alquran Hadis adalah bagian dari mata pelajaran pendidikan agama Islam di Madrasah Aliyah yang dimaksud untuk memberi motifasi, bimbingan, pemahaman, kemampuan dan penghayatan terhadap isi yang terkandung di dalam Alquran dan Hadis sehingga dapat diwujudkan dalam perilaku sehari-hari sebagai perwujudan iman dan taqwa kepada Allah SWT. Mata pelajaran Alquran Hadis didalamnya membahas ayatayat Alquran dan beberapa Hadis pilihan yang berisi tentang segala aspek kehidupan manusia. Oleh karena itu mata pelajaran Alquran Hadis pada tingkat Madrasah Aliyah perlu untuk ditimgkatakn tentang pemahamannya agar dalam menjalani kehidupan sehari-hari bisa sesuai dengan tuntunan agama Islam.

\section{METODE PEMBELAJARAN ALQURAN HADIS PADA KELAS XI IPK DI MAN 2 BUKITTINGGI}

Guru merupakan salah satu pihak dalam dunia pendidikan yang memegang peranan penting untuk mengarahkan siswa agar berhasil dalam kegiatan proses belajarnya. Guru sebagai salah satu unsur penentu keberhasilan belajar siswa bisa menjadi seorang yang pandai dan berhasil.

Sebagai seorang guru, guru harus bisa menjadi seseorang yang profesional. Jadi, untuk menjadi guru yang profesional guru harus bisa dalam segala hal mengajar. Salah satunya sebelum proses belajar mengajar guru harus mempersiapkan segala sesuatu dengan maksimal, agar dapat menyampaikan materi pelajaran kepada siswa secara sistematis dan tepat, sehingga dapat tercapai tujuan pembelajaran seperti yang diharapkan.

Agar tercapai tujuan pembelajaran seperti yang diharapkan, maka guru harus mempersiapakan segala sesuatu yang berhubungan dengan materi yang akan diajarkan. Baik itu menyiapakan bahan, rpp, silabus, strategi, metode, dan media yang cocok dengan materi pelajaran. 


\section{Persiapan Sebelum Proses Pembelajaran Berlansung}

Berdasarkan hasil observasi yang penulis lakukan di MAN 2 Bukittinggi, bahwa persiapan sebelum proses pembelajaran sudah dibuat oleh guru Alquran Hadis, baik itu pemilihan materi yang diajarkan, menyediakan sumber bahan pelajaran, pembuatan rpp dan silabus, dan membuat rangkuman materi pelajaran. Hal ini penulis dapatkan dengan melihat perangkat mengajar yang dibuat oleh guru Alquran Hadis.

penulis melakukan wawancara dengan guru mata pelajaran Alquran Hadis tentang persiapan beliau sebelum memulai proses belajar mengajar, beliau menyatakan bahwa:

"Sebelum dilaksanakannya proses pembelajaran atau sebelum saya masuk kelas, terlebih dahulu saya memilih materi yang diajarkan, menyediakan bahan dan sumber pelajaran, membuat uraian materi, membuata rancangan program pembelajaran (RPP) yang lengkap dengan strategi, metode dan media yang akan digunakan. Memprsiapkan segala sesuatu yang berhubungan dengan yang diajarkan akan mempermudah dan terarahnya saya dalam melaksanaka proses belajar mengajar, sehingga tercapai tujuan pembelajran yang diharapkan." 24

Dalam membuat atau merancang program pembelajaran ada beberapa hal yang harus diperhatikan oleh guru bidang studi, yaitu:

1. Kurikulum, yaitu semua kegiatan atau pengalaman belajar yang didesain di bawah tanggung jawab sekolah dalam rangka mencapai tujuan-tujuan yang telah ditetapkan. Kurikulum sebagai program pembelajaran bagi siswa bercirikan: 1) memiliki tujuan yang ingin dicapai, 2) isi

24 Aliswar Refzan, Guru Mata Pelajaran AlQur'an Hadits, wawancara Pribadi, MAN 2 Bukittinggi, 14 Januari 2019 program yang harus diberikan, 3) memiliki strategi dalam melaksanakan program tersebut, dan 4) evaluasi.

2. Karakter siswa, yaitu karakteristik individu yang dimiliki oleh siswa yang meliputi: 1) motivasi, 2) gaya berfikir, 3) minat belajar siswa, dan 4) latar belakang siswa.

3. Sumber belajar, yaitu segala sumber yang dapat memfasilitasi untuk melaksanakan proses pembelajaran guna mencapai tujuan.

Berdasarkan hasil observasi dan wawancara di atas penulis berkesimpulan bahwa mempersiapkan segala sesuatu yang berhubungan dengan apa yang akan diajarkan adalah hal yang terpenting dan harus dilakukan sebelum proses pembelajaran berlansung. Agar pelaksanaan pembelajaran berjalan dengan baik dan terarah sehingga tujuan pembelajaran tercapai secara optimal. Tampa adanya persiapan yang baik, proses pembelajaran akan menjadi kurang bermakna, artinya proses pembelajaran yang dilakukan akan menjadi kurang efektif.

\section{Menentukan Metode Yang Dipakai}

Penentuan metode sama pentingnya dengan persiapan sebelum mengajar, karena metode akan menetukan berhasil atau tidaknya suatu pembelajaran nantinya. Berdasarkan hasil observasi yang penulis lakukan, sebelum proses pembelajaran berlansung, guru Alquran Hadis sudah mempersiapkan segala sesuatu yang berhubungan dengan apa yang diajarkan, seperti perangkat pembelajaran, yang di dalamnya sudah ada materi, strategi, metode, dan medianya.

Berdasarkan hasil wawancara penulis dengan guru mata pelajaran Alquran Hadis, guru tersebut menyatakan bahwa:

"Seperti yang saya katakan tadi, sebelum saya melakukan proses belajar mengajar, saya mempersiapkan terlebih dahulu apa-apa yang berhubungan dengan proses pembelajaran. Apalagi metode, saya memilih metode yang 
tepat sesuai dengan materi yang akan saya ajarkan.,25

Berdasarkan hasil observasi dan wawancara di atas dapat penulis tarik kesimpulan bahwa pemilihan metode pembelajaran harus dilihat dari materi yang akan diajarkan.

\section{Penggunaan Metode Yang Bervariasi}

Menggunakan metode yang bervariasi sangat bagus dalam proses pembelajaran, karena dengan menggunakan metode yang bervariasi pembelajaran akan lebih menarik, dan siswapun akan lebih bersemangat dalam belajar. Jika penggunaan metode tidak bervariasi atau monoton akan menyebabkan siswa bosan dalam belajar. Berdasarkan hasil observasi penulis dalam pemakaian metode yang bervariasi ini, guru Alquran Hadis menggunakan metode yang bervariasi sesuai dengan keadaan kelas dan materi pembelajaran yang ada.

Sebagaimana terdapat pada hasil wawancara penulis dengan guru Alquran Hadis, beliau menyatakan bahwa:

"Menurut saya penggunaan metode yang bervariasi itu memang penting. Sangat bagus dilakukan pada saat mengajar. Karena akan membuat siswa bisa lebih bersemangat dalam belajar. Tapi, menggunakan metode yang bervariasi ini harus melihat dari segi waktu, kalau waktu tidak mencukupi maka menggunakan metode bervariasi tidak akan terlaksana dengan baik. Saya selalu menggunakan metode yang bervariasi ketika mengajar."26

Ketika dilakukan wawancara dengan siswa kelas XI IPK, apakah bapak menggunakan metode yang bervariasi dalam mengajar. siswa tersebut mengatakan bahwa:

25 Aliswar Refzan, (Guru Mata Pelajaran AlQur'an Hadits), Wawancara, Bukittinggi, 14 Januari 2019. ${ }^{26}$ Ibid.
"Menurut saya penggunaan metode yang bervariasi sangat penting karena membuat kami sebagai siswa lebih bersemangat dalam belajar, kebanyakan guru kan menggunakan metode yang monoton, tetapi tidak dengan bapak Liswar, beliau mengajar kami dengan berbagai macam metode sehingga membuat kami tidak ngantuk dan bosan dalam belajar. ${ }^{, 27}$

Ada juga siswa kelas XI IPK yang mengatakan bahwa:

"Kalau saya juga lebih suka guru mengajar kami dengan metode yang bervariasi, karena juga membuat saya lebih semangat dalam belajar. Contohnya saja jika guru menegaplikasikan metode diskusi, ceramah, tanya jawab dan metode demonstrasi. Maka disitu tidak ada peluang bagi kami untuk mengantuk. Karena yang awalnya kami disurub diskusi yang mana kami saling bertukar pikiran, selanjutnya guru menjelaskan dengan metode ceramah tentang materi yang belum kami ketabui, selanjutnya guru baru menggunaan metode tanya jawab jika ada yang tidak kami pahami. Maka disitu tidak ada peluang bagi kami untuk mengantuk.."28

Dari hasil observasi dan wawancara di atas dapat disimpulkan bahwa metode yang bervariasi sangat penting dan bagus dalam pembelajaran. Karena dengan metode yang bervariasi proses belajar mengajar akan lebih menarik. Siswa pun tidak akan mengantuk dan bosan dalam mengikuti proses belajar mengajar.

\section{METODE YANG DIGUNAKAN DALAM PEMBELAJARAN ALQURAN HADIS}

Guru yang baik pada dasarnya adalah manusia yang baik, guru yang memiliki kepribadian penyayang, baik, sabar, tegas, pekerja keras, serta berkomitmen pada pekerjaan mereka. Pusat perhatian mereka

27 Alvina Damayanti, (Siswa Kelas XI IPK 2), Wawancara, Bukittinggi, 14 Januari 2019

28 Gita Novita Sari, (Siswa Kelas XI IPK 2), Wawancara, Bukittinggi, 14 Januari 2019 
bukanlah pada buku teks, tetapi pada anak, mereka sangat menyadari beragamnya cara belajar siswa, perbedaan antara siswa dan petingnya metode beragam untuk mendorong siswa mampu belajar.

Sebagai guru agama Islam pada mata pelajaran Alquran Hadis yang mengajar di kelas XI IPK MAN 2 Bukittinggi, tentu mempunyai metode selama proses belajar mengajar berlangsung, agar proses belajar mengajar berjalan dengan baik. Metode merupakan cara yang digunakan seorang guru dalam proses belajar mengajar dan menyesuaikan dengan kondisi yang terjadi di lapangan sehingga tercipta seorang guru yang profesional.

Adapun metode mengajar yang digunakan oleh bapak Liswar Refzan dalam mengajar Alquran Hadis adalah:

\section{Metode Hafalan dan Demonstrasi}

Berdasarkan hasil wawancara penulis dengan guru Alquran Hadis, beliau menyatakan bahwa:

"Metode ini digunakan apabila ada siswa yang dikasib tugas oleb guru untuk menghafal ayat di rumah kemudian minggu depan dipraktekan di depan tanpa melibat Alquran". 29

Penjelasan dari bapak tadi juga diperkuat dengan hasil wawancara terhadap siswa:

"Menurut Salwa metode hafalan digunakan bapak Liswar apabila kami disurub untuk. menghafala ayat kemudian kami praktekan di depan kelas tanpa melihat Alquran dan buku pelajaran Alquran Hadis "'30

Sebagaimana didukung oleh hasil wawancara dengan siswa kelas XI IPK yang lainnya:

29 Aliswar Refzan, Guru Mata Pelajaran AlQur'an Hadits, wawancara Pribadi, MAN 2 Bukittinggi, 14 Januari 2019

30 Salwa Nadia, Siswa Kelas XI IPK 2, Wawancara Pribadi, MAN 2 Bukittinggi, 14 Januari 2019 "menurut Vina metode hafalan dipakai bapak. Liswar apabila kami disurub untuk. menghafal ayat atau Hadis yang sudah kami pelajari, dan dipratekan minggu depan sebelum proses pembelajaran dimulai ke depan kelas. Tapi metode ini hanya sekali kali dipakai bapak dalam mengajar kami, hanya permulaanya saja ${ }^{31}$

Menurut penulis metode hafalan dan demontrasi sudah cocok digunakan dalam pembelajaran Alquran Hadis, karena menghafal memiliki tujuan agar selalu ingat dengan sesuatu yang telah dihafal.

\section{Metode Tanya Jawab}

Berdasarkan hasil pengamatan penulis, metode ini digunakan oleh bapak Liswar apabila ada siswa yang kurang mengerti dengan yang disampaikan oleh guru. Siswa menanyakan kembali kepada guru tentang pelajaran yang kurang dipahami oleh siswa tersebut. Kemudian guru menjelaskan kembali supaya siswa lebih mengerti. Atau bisa juga metode ini digunakan oleh guru untuk menguji sampai dimana pemahaman siswa terhadap materi yang telah diuraikan.

Menurut Abdul Toha siswa kelas XI IPK 2 MAN 2 bukittinggi, siswa tersebut menjelaskan bahwa:

"metode tanya jawab digunakan bapak. Liswar apabila kami kurang mengerti apa yang disampaikan oleb bapake guru kemudian kami menanyakan kembali kepada bapak. Kemudian bapak Menjelaskan kembali sampai kami mengerti dengan materi yang diajarkan. ${ }^{\text {22 }}$

Menurut penulis dengan mengunakan metode tanya jawab siswa dapat memahami pelajaran, melatih dan memberanikan siswa untuk belajar mengekspresikan lisan yaitu dengan bertanya.

31 Alvina Damayanti, Siswa Kelas XI IPK 2, Wawancara Pribadi, MAN 2 Bukittinggi, 14 Januari 2019

32 Abdul Toha, Siswa Kelas XI IPK 2, Wawancara Pribadi, MAN 2 Bukittinggi, 14 Januari 2019 


\section{Metode Ceramah}

Metode ini dipakai bapak Liswar setiap kali mengajar, karena menurut bapak Liswar metode ceramah metode yang tidak bisa di tinggalkan, metode yang cocok untuk semua materi, karena kalau tidak dengan metode ceramah, bagaimana menjelaskan apa yang tidak dimengerti siswa. Disaat proses belajar mengajar berlangsung siswa kelas XI IPK 2 MAN 2 Bukittinggi yaitu Abdul Toha mengatakan bahwa bapak Liswar mengunakan metode ceramah setiap kali mengajar.

Didukung juga oleh hasil wawancara dengan siswa yang lain, yaitu;

"Menurut Zukri, bapak Liswar dalam mengajar kami selalu memakai metode ceramah, terkadang membuat kami bosan dengan metode yang dipakai dan membuat kami mengantuk belajar." 33

Menurut pendapat penulis metode ceramah sudah cocok digunakan dalam pembelajaran Alquran Hadis, alangkah lebih baiknya metode ceramah divariasikan dengan metode lain supaya tidak membuat siswa bosan.

\section{Metode Diskusi}

Dari hasil observasi penulis, guru menggunakan metode diskusi pada saat siswa dihadapkan pada suatu masalah, yang bisa berupa pertanyaan, dimana siswa tersebut saling bertukar pendapat dalam menyelesaikan permasalahan tersebut.

Menurut Abdul Toha, siswa kelas XI IPK 2 mengemukakan bahwa:

"Metode diskusi dipakai bapak apabila bapak memberi tugas untuk dikerjekan secara berkelompok, dimana kelompok satu saling beradu pendapat dengan kelompok yang lain, metode ini hanya sekali kali dilakukan bapak kepada

33 Zukri Budiman, Siswa Kelas XI IPK 2, Wawancara Pribadi, MAN 2 Bukittinggi, 14 Januari 2019 kami. Bapak sering mengajar dengan metode ceramah." ${ }^{34}$

Menurut penulis dengan memakai metode diskusi membuat murid aktif, siswa lebih aktif dalam bermusawarah, terlatih dan menghargai pendapat orang lain.

\section{Penggunaan Metode Ceramah Dalam Menyampaikan $\underline{\text { Materi }}$}

Metode ceramah telah lama diterapkan di Indonesia. Penerapan metode ini ditandai dengan penyajian materi pembelajaran yang dilakukan guru dengan penuturan atau penjelasan lisan secara lansung kepada siswa. Informasi lisan yang disampaikan guru mendominasi proses belajar mengajar sehingga siswa hanya sebagai komunikan ( penerima infirmasi). Oleh karena itu guru senantiasa dituntut untuk aktif dan menguasai materi dengan baik. Namun, semenjak perubahan kurikulum pada tahun 2004, dimana saat itu pemerintah berupaya memperbaiki mutu pendidikan dengan mencanangkan kurikulum berbasis kompetensi (KBK), metode ceramah tidak lagi menjadi metode utama dalam proses belajar mengajar. Metode ini dinilai kurang mendorong keaktifan siswa dalam mengolah materi pelajaran dan menjadikan mereka sangat pasif, siswa pun sangat mungkin menjadi kurang antusias dalam mengikuti pelajaran karena pola yang terlalu monoton. Sebagaimana hasil observasi penulis menemukan bahwa metode ceramah selalu dipakai guru alqur'an Hadis dalam mengajar.

Sebagaimana hasil wawancara dengan guru bidang studi Alquran Hadis yaitu:

"Iya, saya selalu menggunakan ceramah dalam belajar, karena metode ceramah adalah metode tertua , metode pertama yang ada. Menurut saya metode ceramah adalah metode

34 Abdul Toha, Siswa Kelas XI IPK 2, Wawancara Pribadi, MAN 2 Bukittinggi, 14 Januari 2019 
yang kebanyakan cocok untuk materi pelajaran Alquran Hadis." 35

Sebagaimana didukung oleh hasil wawancara dengan siswa kelas XI IPK yaitu:

"Menurut Salwa bapak selalu mengajar dengan metode ceramah, hanya sekali kali menggunakan metode yang lain, terkadang metode yang dipakai bapak dalam mengajar membuat kami bosan dan ngantuk dalam belajar." 36

Dari hasil wawancara di atas dapat penulis simpulkan bahwa bapak selalu memakai metode ceramah dalam mengajar, karena materi Alquran Hadis butuh penjelasan yang banyak, sehingga tidak bisa dielakkan penyampaian materinya dari metode ceramah. Menurut saya memakai metode ceramah memang baik, tetapi alangkah lebih baiknya apabila divariasikan dengan metode yang lain supaya siswa tidak jenuh dalam belajar.

\section{Penggunaaan Metode Diskusi Dalam Mengajar}

Metode pembelajaran merupakan suatu cara yang digunakan untuk mencapai tujuan pembelajaran. Salah satu metode yang dapat digunakan oleh guru dalam proses pembelajaran yang bertujuan untuk meningkatkan kemampuan peserta didik yaitu metode diskusi. Metode diskusi adalah komunikasi seseorang dengan orang lain dan saling bertukar pendapat.

Namun setiap metode pembelajaran yang diberikan pastinya ada kelebihan dan kelemahannya, sehingga guru harus memahami berbagai metode pembelajaran agar guru dapat memilih metode yang tepat dan sesuai materi dan tujuan pembelajarannya. Metode pembelajaran yang digunakan diharapkan mampu meningkatkan kemampuan peserta didik dalam proses berpikir dan mengemukakan pendapat.

35 Aliswar Refzan, Wawancara, 14 Januari 2019

36 Salwa Nadia, (Siswa Kelas XI IPK 2), Wawancara, Bukittinggi, 14 Januari 2019
Sebagaimana hasil wawancara dengan guru bidang studi Alquran Hadis tentang penggunaan metode diskusi dalam mengajar,yaitu:

"Iya, saya ada memakai metode diskusi supaya anak bisa memperluas wawasannya dan bertukar pikiran dengan teman-teman yang lain. ${ }^{\prime 37}$

Sebagaimana didukung oleh hasil wawancara dengan siswa kelas XI IPK MAN 2 Bukittinggi yaitu:

"Menurut Zukri, iya bapak ada mengajar kami dengan menggunakan metode diskusi, ketika kami dibarikan suatu tugas atau pertanyaan dan disurub mencari jawaban tersebut secara berkelompok, "38

Dari hasil wawancara di atas dapat disimpulkan bahwa bapak ada memakai metode diskusi ketika memberikan tugas kepada siswa untuk memecahkan suatu masalah dan dicari jawabannya secara bersama.

\section{KENDALA YANG DIHADAPI GURU DALAM PELAKSANAAN METODE PEMBELAJARAN ALQURAN HADIS}

Dalam melaksanakan metode mengajar, maka seorang guru akan mengalami kendala-kendala dalam menerapkannnya. Sebagaimana hasil wawancara dengan guru bidang studi Alquran Hadis yaitu:

"Kendala saya dalam penerapan metode pembelajaran Alquran Hadis adalab karena kurangnya sarana prasarana yang mendukung metode pembelajaran, seperti ketersediaan infocus dan minimnya waktu pembelajaran". 39

Dari hasil wawancara di atas dapat penulis pahami bahwa kedala bapak dalam penerapan metode adalah karena kurangnya sarana prasarana seperti media infocus dan juga waktu pembelajaran yang hanya dua jam dalam seminggu.

${ }^{37}$ Aliswar Refzan, Wawancara, 14 Januari 2019.

38 Zukri Budiman (Siswa Kelas XI IPK 2), Wawancara, Bukittinggi, 14 Januari 2019

39 Aliswar Refzan, Wawancara, Bukittinggi, 14 Januari 2019 
Sebagaimana didukung oleh hasil wawancara dengan guru Alquran Hadis yaitu:

"Sarana yang saya butubkan dalam menerapkan metode seperti in focus dan waktu pembelajaran paling kurang empat jam pelajaran dalam seminggu."

Dilihat dari latar belakang pendidikan siswa sebelumnya, ada sebagian kecil dari siswa yang belajar di MAN 2 Bukittinggi dengan latar belakang pendidikan sebelumnya dari pendidikan umum atau SLTP.

Sebagaimana hasil wawancara dengan siswa kelas XI IPK MAN 2 Bukittinggi yaitu:

"Menurut Zukri, metode bapak mengajar sudab bervariasi dengan mengkolaborasikan metode-metode yang ada, seperti metode ceramah, tanya jawab, dan metode diskusi. Namun ada sebagian kecil dari kami yang latar belakang pendidikan sebelumnya dari SLTP, sebingga kami belum mengetahui materi yang sebagian dari teman-teman lain sudah terlebih dabulu tabu Karen merek dari Madrasab Tsanawiyah."

Dalam melaksanakan segala sesuatu harus didukung oleh sarana prasarana yang lengkap. Sebagaimana didukung oleh hasil wawancara dengan guru bidang studi Alquran Hadis yaitu;

'Dalam pelaksanaan metode harus didukung oleh sarana prasarana yang lengkap, contohnya alat media dan buku sumber belajar yang mendukung berjalanya pelaksanaan metode yang baik." +2

Untuk mengajarkan materi Alquran Hadis di MAN 2 Bukittinggi, guru hanya diberi kesempatan 2 jam pelajaran dalam satu minggu dengan alokasi yang tersedia tidak cukup untuk

40 Aliswar Refzan, Guru Mata Pelajaran AlQur'an Hadits, wawancara Pribadi, MAN 2 Bukittinggi, 14 Januari 2019

41 Zukri Budiman, Siswa Kelas XI IPK 2, Wawancara Pribadi, MAN 2 Bukittinggi, 14 Januari 2019

42 Aliswar Refzan, Guru Mata Pelajaran AlQur'an Hadits, wawancara Pribadi, MAN 2 Bukittinggi, 14 Januari 2019 melaksanakan proses pembelajaran dengan metode yang bervariasi. Hal ini sesuai dengan apa yang dikatakan guru bidang studi Alquran Hadis, bahwa:

"Untuk menerapkan metode pembelajaran yang bervariasi membutubkan waktu yang banyak, sementara waktu yang tersedia untuk menjelaskan materi pembelajaran saja. Kadang-kadang tidak cukup. Alas an lain juga dikarenakan dengan waktu yang 2 jam pelajaran banya efektif digunakan untuk menjelaskan teori secara rutin.",

Dari hasil wawancara diatas dapat disimpulkan bahwa kendala yang dihadapi dalam pelaksanaan metode adalah karena kurangnya sarana prasarana yang mendukung jalanya metode pembelajaran. Dan juga karena kondisi kemampuan siswa juga rata-rata menengah kebawah sehingga membuat proses belajar mengajar menjadi tidak efektif atau berjalan dengan baik. Dari segi waktu yang sedikit membuat guru juga tidak bisa mengunakan metode yang bervariasi.

\section{KESIMPULAN}

Hasil penelitian ini menunjukkan bahwa metode pembelajaran Alquran Hadis pada kelas X IPK di MAN 2 Bukittinggi, dapat disimpulkan beberapa hal.

Metode hafalan dan demontrasi, metode ini digunakan apabila guru memberi tugas seperti menghafal ayat kemudian dipraktekan di depan kelas tanpa melihat Alquran.

Metode tanya jawab, metode ini digunakan oleh guru Alquran Hadis dalam mengajar apabila ada siswa yang kurang mengerti dengan apa yang disampaikan guru, maka disni guru memberikan kesempatan kepada siswa untuk mengajukan pertanyaan.

Metode ceramah, metode ini digunakan oleh guru Alquran Hadis dalam penyampaian materi, biasanya metode ini

43 Aliswar Refzan, Guru Mata Pelajaran AlQur'an Hadits, wawancara Pribadi, MAN 2 Bukittinggi, 14 Januari 2019 
dugunakan guru pada saat awal-awal proses pembelajaran Alquran Hadis berlansung.

Metode diskusi, dimana siswa dibentuk dalam beberapa kelompok. setiap kelompok akan dihadapkan pada suatu masalah yang bisa berupa pertanyaan,atau pernyataan yang diberikan guru. Maka setiap kelompok tersebut saling bertukar pendapat dalam menyelesaikan permasalahan tersebut. 


\section{DAFTAR KEPUSTAKAAN}

Ahmadi, Abu \& Joko Tri Prasetya, Strategi Belajar Mengajar, Bandung: CV Pustaka Setia, 2005.

Alizamar, Toeri Belajar dan Pembelajaran; Implementasi dalam Bimbingan Kelompok Belajar di Perguruan Tinggi, Yogyakarta: Media Akademik, 2016.

Ed.,Undang-Undang Republuk Indonesia No 20 Tabun 2003 tentang Sistem Pendidikan Nasional, Jakarta: Sinar Grafika, 2009.

Ed., Al-Qur'an dan Terjemahannya, Jakarta: Pustaka Alfatih, 2011.

Fadillah, M., Implementasi Kurikulum 2013 dalam pembelajaran SD/MI, SMP/MTs \& SMA/MA, Yogyakarta: Ar-Ruzz Media, 2014.

Fathurrohman, Pupuh \& M. Sobry Sutikno, Strategi Belajar Mengajar, Bandung: PT. Refika Aditama, 2007.

Hamalik, Oemar, Media Pembelajaran, (Bandung: Citra Aditya Bakti, 1989.

Hamzah, Perencanaan Pembelajaran, Jakarta: Bumi Aksara, 2008.

Muliati, Indah, and Muhamad Rezi. "Tujuan Pendidikan Dalam Lingkup Kajian Tafsir Tematik Pendidikan." Islam Transformatif: Journal of Islamic Studies 1, no. 2 (2018): 177-90. https://doi.org/10.30983/IT.V1I2.475.

Moleong, Lexy J, Metodologi Penelitian Kualitatif, Bandung: Remaja Rosda Karya, 2006.

Sanjaya, Wina, Strategi Pembelajaran Berorientasi Standar Proses Pendidikan, Jakarta: Kencana, 2008.

Sanjaya, Wina, Strategi Pembelajaran, Jakarta: Kencana, 2006.

Suryono dan Hariyanto, Belajar dan Pembelajaran Toeri dan Konsep, Bandung: Remaja Rosdakarya, 2017.

Tafsir, Ahmad, Metodologi Pengajaran Agama Islam, Bandung: PT. Remaja Rosdakarya, 2007.

Tambak, Syahraini, Pendidikan Agama Islam Konsep Metode Pembelajaran PAI, Yogyakarta: Graha Ilmu, 2004.

Umar, Bukhari, Ilmu pendidikan Islam, Jakarta: Amzah, 2010.

Uno, Hamzah B., Model Pembelajara Menciptakan Proses Belajar Mengajar yang Kreatif dan Efektif, Jakarta: Bumi Aksara, 2008.

Yusuf, Muri, Pengantar Ilmu Pendidikan, Jakarta: Ghalia Indonesia, 1986 